\title{
The figure of the officer: class, gender, and military hierarchy in the Swiss army in the 1930s and 1940s
}

\author{
Christof Dejung University of Konstanz
}

\begin{abstract}
Taking the example of military education and everyday life in the Swiss army during the World War II, this article aims to address two issues that have so far only found marginal consideration in most studies of military history. First, the article attempts to explore in what way the military hierarchy was gendered, thus borrowing from Joan Scott's argument that the category of gender can be useful for studying power relationships within social institutions. Second, it will discuss the extent to which this gendered system of command and subordination was linked with the concept of class and it will examine the role of the army as a training camp for establishing relations of social power. It will be argued that the figure of the officer functions to interconnect these two aspects, since it incorporated a form of manliness which can be characterized as hegemonic masculinity.
\end{abstract}

In 1944 , the author of a conjugal guidebook claimed that ${ }^{1}$ :

The soldier is the manly man who is not afraid and who risks his life for his ideals of freedom and fatherland. The woman feels it clearly and certainly that she would not be able to fulfil her duty as a housewife and a mother without these manly goods of spiritual life. That is why for her the soldier is the essential, the complete man. (Hanselmann 1944: 155)

Such declarations were frequent in Switzerland during the Second World War. As in many modern nations in the nineteenth and twentieth century, especially during periods of military conflict, the soldier was regarded as the embodiment of masculinity, adored by a female audience (Mosse 1996: 107-19; Frevert 1997a; Kühne 1999; Nye 2007).

In several studies, however, it has been revealed that military masculinity is a much more ambiguous concept. Military comradeship for instance included tenderness and caring for other men. In other words it could feature attributes characterized as distinctly female in civil life, as Thomas Kühne (1997) and Joanna Bourke (1996: 126-37) have pointed out. Yet, what has not been considered in most studies to date is the possible relationship between rank and different ascriptions of masculinity. In what way does the perception of the soldier change when it is compared with the figure of the officer? This article attempts to explore first to what extent the military hierarchy was gendered, thus borrowing not least from

\section{Keywords}

class everyday life gender hegemonic masculinity military education World War II Switzerland

1. The quotations in this article are originally in German. All translations are my own. 
2. The period of military service has been extended several times since the end of the nineteenth century. In 1939, every conscript had to complete a basic military training of 118 days. Privates then had to attend seven refresher courses and one complementary course of twenty days each. Corporals, however, had to attend corporals' school which lasted eighteen days after graduation from basic military training. Afterwards they had to 'merit' their corporal's rank in another course of basic military training. Aspirants then attended officer's school which lasted 88 days and had to 'merit' their rank of a lieutenant in another course of basic military training of 118 days. Further officer's grades had to be earned by attending special courses and military schools (Kurz 1985: $15-21$ and 105 Tanner 1997: 323f.).
Joan Scott's (1986) classical argument that the category of gender can be a very useful category for studying power relationships within social institutions. It will examine the ways in which the army as a distinctly male institution usurped discourses and practices from the civil gender order to legitimate the distribution of power between soldiers and officers.

The second problem this article will tackle is the extent to which this gendered system of command and subordination was linked with the concept of class. This too is a question that has not yet received the attention it merits. The military generally has a close relationship with the social order since the army is the institution in which the state's monopoly of power is legitimately concentrated, as Ute Frevert (1997b) has pointed out. Therefore it is not surprising that the Swiss army was a distinctly bourgeois institution and its officers came mostly from the upper class (Jaun 1999: 196f). But what were the consequences of this for military education? As in other modern nations, basic military training in Switzerland fulfilled the function of a rite of passage in the accession to true masculinity, and had to be undertaken in order that young males became full citizens. Therefore, since the nineteenth century, the Swiss army has been referred to as the 'school of the nation' (Tanner 1997; Jaun 1999). This article will discuss the extent to which the Swiss army was not only an organization for the defence of the country, but a training camp, in which young men were transformed into real men and relations of social power were established and taught to the conscripts.

It will be argued further that the figure of the officer functions to interconnect these two aspects, since it incorporated a form of masculinity which adopted hegemonic features in wartime Switzerland. In his analysis of the concept of hegemonic masculinity, Robert W. Connell (1995) described the predominance of a certain mode of masculinity over other, inferior forms of manliness such as homosexual, Jewish or working-class masculinity. The concept certainly poses certain problems, not least since it is almost impossible to examine the exact bearing of a certain trait of masculinity on a given society. Furthermore, there are different forms of masculinity, which could each be attributed hegemonic status in a particular social context (Dinges 2005). Nevertheless, hegemonic masculinity continues to be an indispensable concept for masculinity studies, not least because of its ability to link cultural attributes of masculinity to social inequality and political power, as John Tosh has maintained (Tosh 2004: 53). Hegemonic masculinity in this understanding is not a mere aftereffect of social order but rather serves as a symbolic tool to support it.

For several reasons, Switzerland is an interesting case study of interactions between military and civil society. The Swiss army was regarded as a model of republican egalitarianism for many decades and is organized strictly as a militia system. Even today there are no professional soldiers in the Swiss army - except for some administrators and a few instructors. All regular soldiers, including those of the highest ranks, are merely part-time soldiers. Only after graduation from basic military training, which is compulsory for all young men fit enough for military service, can soldiers who aspire to a military career attend subsequent training schools. ${ }^{2}$ There is no separate education for prospective officers, reserved for upper class men, as in other European countries. For many decades, this permeability 
between military and civil society made it very plausible that military education should serve educational purposes in civil life. Another reason why the Swiss case is of special interest lies in the fact that Switzerland was one of the very few countries in Europe that was not directly involved in the Second World War. ${ }^{3}$ Precisely because the Swiss army did not have to fight, its symbolic impact on society was not challenged by the brutality of modern warfare and could prevail during the wartime years and for many decades afterwards (Dejung 2007).

By investigating the role of the army in the internalization of certain discourses on class and gender, this article deals with the question of identity. As Michael Roper (2005) has pointed out, gender historians often draw conclusions from the analysis of normative texts on actual attitudes and self-perceptions. Yet the relationships between discourses and identities in their studies, Roper claims, remain rather speculative. Therefore, it is important to investigate the impact of these normative texts on the everyday life of men and women and on the routines that lead to their internalization. For this reason I will not only analyse the contemporary military discourse present in official pamphlets and theoretical publications by officers, but also the self-perceptions of soldiers and women contained in their descriptions of the military during the wartime years to investigate their perceptions of military masculinity at that time. ${ }^{4}$

The article is organized into five sections. The first section describes how the socio-political consensus of the Spiritual Defence and the threat of a German invasion led to a revaluation of the army and to a polarization of gender roles in the 1930s. The second section describes how the military hierarchy was characterized by an ascription of different traits of masculinity to soldiers and officers. The third section examines the extent to which a military career was reserved only for members of the upper class, while men from lower classes rarely had the opportunity of becoming an officer. The fourth section will describe how women's admiration of military masculinity, and especially of the masculinity of officers, sustained the system of command and subordination in the army, and with it the social order in civil life during the wartime years. The fifth section will show that the army was described explicitly as an institution for socializing young men into the class system by contemporary military theorists.

\section{Polarization of gender roles during the $1930 \mathrm{~s}$}

The notion of the Swiss army being a school of the nation was directly linked to the failing of the political expectations of liberalism at the end of the nineteenth century. The liberal utopia of a society able to integrate all social strata was shattered by the social antagonisms of the industrial society. With the Social Democratic Party, a new political power could take root, which demanded nothing less than the overthrow of the prevailing social order. In this situation, the bourgeoisie hoped that the army would act as a brace to prevent Swiss society from breaking apart (Lengwiler 1995: 179ff; Jaun 1995: 117). The military as an institution of socialization, of course, was far from politically neutral. Since the turn of the century, the army had been deployed regularly to suppress strikes and leftist demonstrations and was therefore in socialist circles referred to as the lifeguards of the bourgeoisie (Jost 1992: 77f; Jaun 1999: 245; Zeller 1999:
3. The other European nations not involved directly in the war were Sweden, the later Republic of Ireland, Portugal, Turkey and Spain (Hobsbawm 1995 24).

4. Since everyday life experiences have very rarely been recorded in written form, oral history is an important source in this article. Some of the interviews presented in this article were conducted for my dissertation (Dejung 2006). Others were conducted with my colleagues for the oral history project Archimob, in which more than 500 contemporary witnesses were interviewed about their experiences in Switzerland during the Second World War. The interviewees belonged to many different groups including soldiers, housewives, workers, farmers, Polish internees and Swiss Jews. The interviews were filmed, and the material of over 1000 hours of testimonials has been used for a TV-documentary series (Rückblickend 2004), two books (Regard and Neury 2002; Dejung, Gull and Wirz 2002) and a multimedia-based exhibition that toured through several Swiss cities (see for more information the project's website http://wrurw. archimob.ch/). The Archimob-interviews are accessible at the Historical Museum, Bern, those of my dissertation at the Archiv für 
Zeitgeschichte, Zürich. 96f, 120f). The culmination of this conflict was the general strike in 1918, which had been put down by armed force (Gautschi 1968). In particular, the fact that the army had not acted as a neutral force during the strike, but had operated on the side of right-wing vigilante groups, lent weight to the leftist notion that the army was a weapon of the bourgeoisie against the claims of the working class. Things changed in the 1930s. In the face of the Nazis' rise to power in Germany and the threat of war, a political consensus between conservative parties and the Social Democrats was reached, which was called Spiritual Defence (geistige Landesverteidigung) (Mooser 1997).

At the same time as this socio-political consensus came about, the quest for the political and economic equality of women suffered a setback. Conservative groups were urging women to devote themselves again to their vocation as mothers and housewives not least because they considered working women as competition for male labourers after the Great Depression. As a consequence, training in housekeeping was put in place in the early 1930s, which became compulsory for all young women. The demands for female suffrage decreased markedly. Women from the political left who had not long ago insisted vehemently on women's rights were now yielding to the new patriotic confraternity of the Spiritual Defence (Joris 1990: 113ff; Mesmer 2007: 147-98).

For the achievement of the Spiritual Defence, the question of military defence played a crucial role. In response to the armament of Germany and Italy, the Social Democratic Party, which until then had been fiercely antimilitaristic, declared that it was going to abdicate from the class struggle, and unconditionally support military defence. The change in policy of the Social Democrats, however, was linked to demands for social and political reforms, which were in fact met right up until the beginning of the war (Imhof 1996; Zimmer 1996). The ideals of the Spiritual Defence also gained importance within the army when the Swiss parliament elected Henri Guisan as Commander in Chief of the Army in August 1939. Guisan came from the French-speaking part of the country, advocated the Republican ideal of the citizen-soldier, and promoted a rapprochement with the Social Democrats (Dejung 2006: 263-88). The appraisal of the army was further promoted by the intensified evocation of the mediaeval founding myth of the Swiss Confederation in the cause of Spiritual Defence. Following this view, Swiss national history was perceived as composed of an everlasting sequence of battles in which the coalition of armed men had preserved the nation's independence against militarily superior enemies (Blattmann 1998: 24).

After the outbreak of war, the army's popularity increased even more because of the perpetual threat of a German invasion (Dejung 2006). The image of the soldier, with perceived virtues such as courage, toughness and the readiness to risk his life for the nation and its populace, was prized in countless propaganda pamphlets during the wartime years. In one brochure for example, the soldierly spirit was characterized solemnly as 'the highest potency of masculinity' (Spinnler 1940: 112), while in another the execution of a military order was described as truly worthy of a man, highest masculinity' (Brühlmeier 1941: 18). The concept of military masculinity, however, required a female counterpart, that is, women who could be seen publicly admiring the soldiers as well as allowing themselves to be 
protected by them. Whereas men could expect to benefit from the concept of military masculinity following their conscription, women had to hope that they were protected by the army in case of an attack. A middle-class woman said in an interview:

I am not a fan of the army, not at all, but somehow, when I saw my husband in his uniform, I sensed: he is a Swiss man. He would fight for his country; he would, in fact, fight for me and my family. Somehow, I was aware of it: these men were ready to sacrifice themselves for us women. (Dejung 19 May 2000 interview)

However, the Swiss army during the Second World War did not exclusively consist of men, despite the emphasis on military masculinity in contemporary propaganda. Between 1940 and 1945, some 20,000 women were engaged in the Female Auxiliary Service (militärischer Frauenhilfsdienst). In this way, Swiss women became officially affiliated to the military for the first time. Members of the Female Auxiliary Service, however, were not armed and they were not provided with a proper uniform, only an apron. With these measures, the Swiss army command aimed to emphasize that the members of the Female Auxiliary Service were only support staff for the army, in the form of office workers, drivers and paramedics, and were not genuine female soldiers. In public, the intrusion of women into the male realm of the army was viewed with scepticism and sometimes outright hostility. Many observers suspected that members of the Female Auxiliary Service were only entering the army in order to get married to an officer or to live out their promiscuity (Stämpfli 2002; Dejung 2005). One woman who had been in the Female Auxiliary Service even recalls that the abbreviation F.H.D. (for Frauenhilfsdienst) was altered to FeldHuren-Dienst (Field Whoring Service) by young men in order to taunt its members (Dejung 19 May 2000 interview).

Thus the discourse on military masculinity was far more than an ideological construct, which only exercised politicians and officers. It was a synonym for social order and an important moral resource for many men and women during the wartime years. In everyday military life, it helped conscripts to cope with the bullying, the senseless commands, exertions and humiliations they had to endure. As compensation for these afflictions, the soldiers could expect to benefit from the concept of military masculinity as a symbolic reward. A soldier noted in 1940 in his diary that despite everything the recruits experienced in the army, basic military training was a good thing since 'it makes them harder and brings them closer to manliness' (Gruner 1973: 150).

The importance of being part of the army and, therefore, being regarded a real man becomes apparent in the descriptions of the physical examination. As in other nations (Bourke 1996: 171-80; Frevert 2001: 240 ), the examination decided who was capable of fulfilling his duty to the nation and who was to be discharged. It consisted of a fitness test and a medical check-up (Hausamann 1938a). As the author of a military educational guidebook wrote in 1941, a young man who was declared fit to enter the army could rightly be proud of himself, since 'from the moment in which the mark "fit for military service" is stamped in his Dienstbüchlein 
5. Swiss Army booklet in which courses attended by servicemen are recorded. (service booklet), ${ }^{5}$ he is assigned to the highest service to his fatherland' (Brühlmeier 1941: 20). Many young men indeed practised for the physical examination to have a better chance of passing it (Dejung 10 March 2000 interview). A veteran recalls in his interview that a young man who was exempt from military service was considered to be a second-class Swiss citizen: 'One had no use for someone like that. A real Swiss man is combat-ready and enters the army. This was the attitude of the time' (Dejung 5 September 2000 interview).

Consequently, the ideology of military masculinity decreased the selfesteem of men who were found unfit for military service. A member of the auxiliary service, who had been declared unqualified for the army, described in a 1942 book the hardships he underwent at the beginning of the war,

on this Autumn morning when the tocsins sounded over our country and called every man fit for military service to their sites of mobilization [. . . ] [while he] had to remain useless at home and had to watch hidden behind the curtains how the real men went to the army. (Kappeler 1942: 308f)

He felt 'inferior and despicable' in his civilian clothes and didn't dare to leave his house since he feared that women would watch him with disapproval. Men who were exempt from military service were lampooned and considered to be inferior during the wartime years. A man for example, who was unfit for service at conscription because he had had problems with his left leg since childhood recalls in his interview: 'If someone was unfit at that time he was called a Staatskrüppel [federal cripple] which is indeed pretty discriminatory' (Dejung 1 December 2000 interview). Women especially did not disguise their disdain for the 'federal cripples'. A woman who came from a working-class background recalled: 'We girls used to laugh at them [...]. We thought they had chickened out and didn't want to defend the country' (Dejung 11 February 2000 interview). This underscores the fact that the grade of masculinity attributed to men depended considerably on the verdicts of women. The high estimation conscripts enjoyed from women during the wartime years, as well as women's scorn for the 'unfit', was an important incentive for young men to fulfil their military duty.

\section{Gender as a discourse of power}

Despite its emphasis on contemporary propaganda it would be disputable to characterize soldierly masculinity as hegemonic as Connell (1995) understands it. This becomes apparent when we take a closer look at military life and particularly at the importance of hierarchy within the army. In fact, the contemporary ideology of gender not only assigned men and women their respective roles during the war and segregated conscripts from men unfit to fulfil their military duty, but it also governed the distribution of power within the military institution. Consequently, the ranks of soldiers and officers were distinguished by a different grade of masculinity. The soldier's masculinity, though emphasized in military propaganda, was distinctively inferior to the higher degree of masculinity of officers, which, according to the following quotation, maintained a hegemonic character at least in the late 1930s. In a pamphlet from 1939, Lieutenant Colonel Edgar 
Schumacher claimed that the officers in the Swiss army 'from the general to the lieutenant' should represent 'the best individuals the state has to offer'. The 'character of the officer' was considered to be the embodiment of the soldierly being, and so the officer's masculinity was beyond question: 'The soldierly ideal of an epoch, a nation is formed according to the character of the officer. [...] All characteristics that we call manly constitute in their harmony the image of the officer' (Schuhmacher 1939: 4f).

The masculinity of privates, in contrast, lost its glamour when it was confronted with the military reality of command. In a military theory text from 1944 an officer wrote that a recruit had to find in his basic military training 'his master. [...] He shall learn to obey, to put himself in his proper place, to subordinate, to control himself, to behave securely, in short, to become a man' (Stampfli 1944: 324). To become a man, in other words, meant regular soldiers were to submit to the authority of the officers without complaint (Erdheim 1982). Military service in fact acted as a form of emasculation for soldiers, since they were systematically deprived of traditional masculine privileges like the freedom of action or self-determination (Hagmann and Trüeb 1989: 121; Kühne 1999). Whereas the soldier's masculinity was only partial, the masculinity of officers was total. Officers were entitled to precisely those privileges that were denied to soldiers. According to contemporary military theorists, the freedom of action and the power to command was the essence of officer's character. Thus, the initiative of the officers was not to be restrained since this would have amounted to a constraint on their masculinity. In an article in the Allgemeinen Schweizerischen Militärzeitung, the journal of the Swiss officer's association, the following warning was given in 1930:

We have to respect our Commanders! They do not need [. . .] any unmanly paternalism and control [. . . . They need confidence and autonomy, for they have to be 'gods' for their subalterns. [.. .] Let us not forget that initiative is the crucial feature of every captain. (Wille 1930: 161f.)

The system of military subordination took further advantage of the fact that the family is a primary source of personal identity and therefore a powerful symbol in legitimizing social order (Roper 2005: 67). Consequently, military hierarchy was sustained by comparing it to the family, with officers taking the place of the father in the patriarchal family order: As in every orderly family, with a father that leads and family members that obey, [. . . ] in the army it is essential that there are superiors who command and subordinates who obey' (Schibler 1907: 31). In the military family, privates did not take up the symbolic place of children, but the place of women. Precisely because women were excluded from the army, the contemporary notion of men's predominance over women was transferred to the military hierarchy and helped to stabilize the system of command and subordination. ${ }^{6}$ The ideology of officers embodying the ideal of masculinity was evidenced by the fact that officers never had to do female labour, such as cooking, cleaning, repairing clothes and so on. For these tasks, which in civil life were the duties of women, they had personal servantsoldiers that were called Putze (cleaners). Privates, on the other hand, had to do this work themselves - often for the first time in their lives. In civil
6. I owe this insight to Däniker (1999). 
society, repairing clothes, cleaning or cooking was done by their mothers, sisters or wives. The fact that the young men called up to the army had to assume these female-connoted duties stands in striking contrast to the contemporary military ideology of the army representing masculinity at its purest.

In warring armies, domestic duties gave soldiers the possibility of experiencing a short period of apparent normality away from the fighting on the battlefield. Swiss soldiers, in contrast, were not involved in wartime conflict. They spent the long months building fortifications and conducting exercises, and most importantly waiting for an enemy that would hopefully never show, until they were released into civil life again only to be called up for another period of military service some months later. Domestic work was, thus, not considered a possible escape from combat but rather constituted evidence of the monotony of military life for many soldiers. To counteract such defeatist attitudes, this kind of work was especially emphasized in contemporary propaganda and military instruction pamphlets. In a booklet from 1940 one could read that by cleaning and mending equipment, 'the most beautiful soldierly attributes can unfold, the discipline in spheres which generally stay unnoticed' (Vetter 1940: $14 f$.). And in a propagandistic article in a magazine from 1938, a serviceman is pictured mending his uniform. The caption reads: 'Lance-corporal Meyer [...] sews a button onto his uniform. With a little will power one can succeed to accomplish what at home is usually done by the faithful wife' (Hausamann 1938b). When soldiers were describing such work, they did it with much less enthusiasm. Apparently annoyed, a soldier wrote in his diary in 1940: 'I have to clean [. . .] the office of our unit like a housewife' (Hugger 1999: 70). This quotation also suggests that a number of servicemen perceived domestic work as a latent threat to their masculinity; hence the reason why several soldiers revealed that, whenever possible, they looked for waitresses in the military canteens or members of the F.H.D. to repair their uniform instead of doing it themselves (Dejung 24 February 2000a and 30 March 2000 interviews).

\section{Congruence of class and military hierarchy}

Military hierarchy was linked not only to gender but also to class. In Swiss military propaganda before and during the Second World War, the army was praised as a model of egalitarianism and it was claimed that no class distinctions existed in the army. In a report on everyday life in a military unit, published in a magazine in 1938, it was asserted that 'nowhere is the distinction between master and servant so blurred as in the army' (Hausamann 1938b: 936). And in a military publication from 1941 this notion was formulated as follows:

In the army [...] [e]verybody, be he the son of a farmer or the son of an upper class man, be he a craftsman or a university student, will be treated and reproved exactly the same way. There are no social differences in our army. (Brühlmeier 1941: 7)

In reality, however, officers came mostly from upper social classes and the military hierarchy corresponded more or less to the hierarchy in civil 
society. The statements quoted above were rather wishful thinking, if not deliberate attempts to hide the class distinctions of the military hierarchy. A military text of 1937 stated, 'Our officers recruit for the most part from the upper and the middle classes. Regarding their education, most officer cadets come from the circles of graduates, businessmen, engineers, teachers' (Frey 1937: 194). One reason for this fact lay in the militia system. All regular soldiers, including those of the highest ranks, were part-time soldiers. In the 1930s and 1940s, however, a military promotion required a certain social background since a military career was a costly undertaking. Not only did the officers have to buy part of their own uniform, which was usually customized and therefore quite expensive, they also had to be able to afford the time off work in order to attend military school and officer-training courses. So simply for economic reasons ordinary workers or farmers seldom had the opportunity to undertake a career in the military, whereas upper-class men regularly became officers.

Another reason for the social stratification of the military hierarchy involved political barriers. Officially, politics did not play a role in the army during the wartime years. Lieutenant Colonel Ernst Uhlmann claimed in 1944 that 'politics had to be distanced from the army. [. . . We know in our army only one kind of Swiss citizen: the soldier, the comrade' (Uhlmann 1944: 406). Contrary to this assertion, however, the army was far from an apolitical institution. Since the end of the nineteenth century, the armed forces helped regularly to suppress strikes and socialist demonstrations. It is, therefore, no surprise that members of the working-class parties were very critical of the army, if not strictly antimilitaristic. Many officers on the other hand would never promote a socialist serviceman to become an officer as this would have given the political enemy control of military power. This worked to great effect; working-class officers were an absolute exception during this period. This did not change with the political consensus of Spiritual Defence. The Social Democratic Party, after its decision to endorse military defence in the late 1930s, appealed repeatedly to the Swiss high command to take action so that servicemen from the working class also had the possibility of advancement in the military hierarchy, with no apparent success. Even though, with the election of Henri Guisan to Commander in Chief of the Swiss army, many of the aspirations of Spiritual Defence were realized within the army, an upper-class background and a rightist attitude remained the pre-condition for a military career (Schmid-Ammann 1939). Therefore, during the war, socialists rarely had the possibility of pursuing a military career. One veteran for example recalls in his interview a comrade who was a member of the Socialist Democratic Party and who was not chosen to become a corporal for exactly this reason (Dejung 10 March 2000 interview).

The mere assumption that in certain units, military rank might not correspond to civil hierarchy was perceived as a threat to the militaristic worldview. A major of a frontier-defence unit responded to the often-made allegation that in these units the social origin of servicemen would 'not always correlate with the military relation of command and subordination' and that 'gross things' could happen like an 'inferior employee becoming the military superior of his chief in civil life', by asserting that in reality in frontier-defence units as well, these 'peculiar disparities between 
civil and military status' were rather the exception that proved the rule. And this rule indicated that in our country people who play a leading and prestigious role in civil life also, in most cases, fill the highest ranks in the army. [. . . ] Generally, the same traits qualify one for leadership in military and civil life' (Hummler 1944: 432f.).

\section{Officer's attitudes and the role of women}

A well-off social background and a rather conservative political attitude were important preconditions for a military career, but the higher degree of masculinity and the social status that came with it had to be earned by prospective officers. After graduation from basic military training and having completed the subsequent corporals' training, officers had to attend officer cadet school which lasted 88 days (Kurz 1985: 15-21, 105). During their education, they had to pass many tests of strength and courage. The cadets for instance had to learn to ride a horse. For cadets who did not come from the upper classes, this was often the first time they had ever sat on a horse and the fact that they had immediately to jump over obstacles in their first riding lesson 'wasn't very enjoyable', as one veteran recalls. Officer cadet school was also physically demanding: After a march of 100 kilometres we had to goose-step with our sabres drawn. Our heels were bleeding. It was very hard, but we thought, that's part of becoming an officer.' Officer cadets who failed these tests were sent home directly (Dejung 7 July 1999 interview).

Officer cadets were therefore taught far more than just how to conduct the trade of war. They had to be toughened up physically and had to overcome their fears. If they passed these tests they could gain additional manliness by rising through the military hierarchy. Officer cadet school was, like graduation from basic military training, a trial of the potential officers' masculinity and a second rite of passage - only to a higher level.

Since officers represented the social elite and were supposed to embody the contemporary ideal of masculinity, the army paid considerable regard to aesthetic considerations. For many contemporary witnesses it was understood that an officer had to be tall, handsome and deft. A small, physically ill-favoured officer candidate would have challenged the noble image of the officer (Dejung 15 December 2000 interview). The attractiveness of the officers was endorsed by the cut of their uniforms. In military regulations, it was emphasized that the officers 'had to be dressed as well as the circumstances allow' in their leisure time. For privates and corporals, however, no corresponding instruction was noted (Dienstreglement 1932: 116). Furthermore, it was fitting that the officers adopted upperclass attributes for their clothing and for their attitude. The cut of the officer's uniform, for instance, was influenced by the riding-clothes of the bourgeoisie. The writer Max Frisch noted in his wartime reminiscences: 'The infantry wears drainpipe trousers which are not only hideous but also dysfunctional whereas the officer appears as a horseman even if he arrives in a jeep' (1974: 135).

To manifest its hegemonic status the officer's representation required an adoring audience. This audience consisted of Swiss women. As I have already argued, women were important for the self-esteem of men fit for military duty, since they admired them and scorned men unfit for the 
army. Women's perception also played a role in sustaining the military hierarchy. This becomes obvious in women's attitudes towards the respective uniforms of soldiers and officers. Their verdict on the uniforms of privates is scathing. One woman, whose father was a shopkeeper, contrasts the appearance of privates and officers:

[The privates'] trousers looked a mess. [. . . ] And the fabric was rough! [. . .] It was no pleasure to look at them. It was so rigid that I figured they always used the same cut and took only two centimetres more cloth if they had to make trousers for a podgy soldier. [Whereas with the officers] well, that was a cut. With an officer they affixed a pad here and a pleat there, he has to represent something after all. (Dejung 24 February $2000 \mathrm{~b}$ interview)

According to such testimony, officer cadets not only had to meet certain physical requirements and were clothed more handsomely than privates, but they also began to move differently and to adopt a new physical bearing after their admission to officer cadet school. Hans Peter Dreier, a former lieutenant, recalls in his interview how his physical bearing changed by wearing his new officer's uniform and boots. He quotes and comments on a remark of his instructor shortly after the beginning of his training course:

'Lieutenant Dreier, you move as if you had been an officer for a year.' I was pleased to hear that, and I had to assume that as an officer you moved differently, you comported yourself differently than before as a soldier, which might be caused by these boots and the uniform, the whole affectation. (Dejung 10 March 2000 interview)

This 'whole affectation' increased the attractiveness of officers for women. During the war, soldiers were very popular with Swiss women, but officers even more so. Dreier recalls that as a lieutenant 'one had immediate success with women. Everywhere. When you went out dancing you could always choose the most beautiful women [...] I became someone. [...] This uniform, this lieutenant's uniform turned a simple man into someone important' (Dejung 10 March 2000 interview).

Officers thus clearly had better chances with women than privates, which simply added to the aura surrounding the rank of officer. This notion is confirmed by another veteran who recalls that women 'liked to be taken out by soldiers, but even more so by officers', and he notes that officers were considered to be more attractive than soldiers: 'If a woman could appear in public hand-in-hand with an officer she could enhance her prestige' (Dejung 15 December 2000 interview). This was not just a male fantasy. Many women approved these statements in their interviews. One middle-class woman said:

It was extremely important. Everyone who had a uniform on was adored by every girl. And if he was a corporal or even outranked one and had done more than just basic military training, he was held in higher esteem than a private. Even if the private was thrice as intelligent. (Dejung 24 February $2000 \mathrm{~b}$ interview) 
Such women's enthusiasm for military men can only be understood in the context of the constant threat of a German invasion of Switzerland during the wartime years. The distinct esteem of women for officers, however, also had to do with class, since a man who wore an officer's uniform in most cases was a member of the upper class or at least the upper middle class. A relationship with such a man was a guarantor of social security. And since officers had not only passed basic military training but had also graduated from officer cadet school, women could conclude that they were physically fit and were therefore a good match.

\section{An institution for socializing young men into the class system}

The correlation of civil and military hierarchy was crucial for the lessons young men were taught in the armed forces beyond using their weapons. Although the army no longer sustained the prevailing social order at gunpoint after the political compromise between Social Democrats and conservative parties in the middle of the 1930s, it nevertheless, supported it by its function as an educational institution. According to the prevailing opinion, the army was supposed to be a school of the state. A military text from 1944 claimed that military training was relevant far beyond the military sphere - it was a prerequisite for "the integration into the "social" community' (Stampfli 1944: 324). According to one military training manual from 1942, military training 'should not only turn Swiss men into soldiers who know about the trade of war! No, military training school has to be a primary school of the state which should work educationally in the first place' ('Wie wir unsere Rekrutenschule erlebten': 1f.) Similarly, in an article in the Allgemeine Schweizerische Militärzeitung, military service was pictured as the last facility of the state to correct 'false civil education' and to 'bring forward its citizens in a positive direction' (Schaer 1940: 57).

Because military hierarchy was basically identical to civil hierarchy, it was the same men in the army as in civil life who wielded power and influence. Young men from the upper class could learn as officers how to command subordinates, whereas members of lower social origin were taught to take orders. The assigned roles of commanders and subordinates were practised deliberately in order to facilitate their later positions in civil life. It was not only the state which could profit from the education that men received in the army, an officer wrote in 1944; the economy benefited as well: Also in the economy [. . .] subordination is necessary. There too, one needs people who are able to command and people who know how to obey. The first shall be learned, the latter has to be taught' (Stampfli 1944: $322 \mathrm{f}$.). Because of this notion, a military career was one way for middleclass men to rise socially. To become an officer was an opportunity to prove experience in leadership and to gain social capital by building networks with upper-class members; it could, therefore, be very helpful in civil life. Up until recent years, in many major Swiss companies, a career in business was only possible if the applicant had a certain rank in the army. Max Frisch describes such an advancement by recalling the later reunion with his captain from the wartime years: 'When I met him later on in civil life he was no more a schoolteacher but a staff manager in the chemical industry in Basel, a man who knew to handle subordinates as he had proved in the army' (Frisch 1974: 137). 
The military education of young Swiss men was also considered to be necessary for reasons of class politics. Despite the political consensus of Spiritual Defence, a group of officers at that time belonged politically to the far right and many of them openly expressed their sympathies with Nazi Germany and Mussolini's Italy (Jost 1992; Zeller 1999; Meier 2004; Neval 2004). These officers were troubled by the idea of socialist uprising but also by the notion that modern society and 'urbanization [...] in Europe resulted in the downfall [. . . ] of white people', as Eugen Bircher, a virulent anticommunist and commander of the 5 th division of the Swiss army noted in 1940 (Bircher 1940: 175). Like many leading officers and rightwing theorists of this period in Switzerland, Bircher saw the military training as a bastion of prevailing society against the threat of bolshevism and the coloured races. Unfortunately, many military theorists of this period were convinced that the majority of the young upper-class men, and thus the greater part of the coming generation of military leaders, were decadent and effeminate, as an officer stated in 1937:

Quite a few of the officers-to-be are, according to their standard of living, not accustomed to simple life, [. . . In contrast to the cosy social environment in which they grew up, they see eating from a tin bowl, bivouacking or sleeping on straw, marching instead of driving, as impertinence. That is why the army comes by future officer cadets [. . . ] who lack the notions of subordination, incorporation, of robustness and hardship. (Frey 1937: 196)

The demanding training undergone in officer cadet school was thus also a measure to counter the bourgeois fear of degeneration. For the survival not only of the existing class system, but also of the Swiss nation itself, it was crucial to have a future generation of strong leaders. It was officer cadet school that, following this notion, had to harden the young men from the upper class for the political conflicts to come.

The explicit announcement of sympathies with fascism and Nazism, quite common among Swiss officers in the 1930s and early 1940s, came to an end when Henri Guisan became Commander-in-Chief of the army and removed many explicit admirers of the totalitarian regimes in Italy and Germany from their posts (Kreis 1976: 180ff.). Even so, the idea of the army as a national reformatory and a distinctly antisocialist institution prevailed until the end of the Cold War. Because Switzerland was one of the very few countries in Europe which had not experienced the devastation of modern warfare, the patriotic and militaristic concepts of the wartime years had not been offset by the brutality of the war, as they had been in other European countries. On the contrary, they had been strengthened and remained influential for many decades. During the cold war, facing the uncertainty of world politics, the majority of Swiss citizens held the view that the independence of the country relied on the existence of a strong army. Switzerland pursued a policy of robust armament after 1945 and became the best-equipped country in Western Europe in terms of numbers of soldiers per square kilometre, and stocks of warplanes, tanks and artillery per capita (Tanner 1997: 318ff., 329). The figure of the officer retained his hegemonic status for many decades. It was only after the late 1960s, when social hierarchies were challenged and leftist intellectual 
circles started to scrutinize the impact of the army on Swiss society, that it slowly began to lose ground.

\section{References}

Bircher, E. (1940), 'Besprechung von Richard Korherr, Volk und Raum, Würzburg 1938', in Allgemeine Schweizerische Militärzeitung, März, pp. 175-6.

Blattmann, L. (1998), 'Männerbund und Bundesstaat', Männerbund und Bundesstaat. Über die politische Kultur der Schweiz, L. Blattmann and I. Meier (eds), Zürich: Orell Füssli, pp. 17-35.

Bourke, J. (1996), Dismembering the Male. Men's Bodies, Britain and the Great War, London: Reaktion Books.

Brühlmeier, B. (1941), Vom Zivilisten zum Soldaten, Aarau: Sauerländer.

Connell, R.W. (1995), Masculinities, Cambridge: Polity Press.

Däniker, K. (1999), 'Die Truppe - ein Weib? Geschlechtliche Zuschreibungen in der Schweizer Armee um die Jahrhundertwende', in C. Eifler and R. Seifert (eds), Soziale Konstruktionen. Militär und Geschlechterverhältnis, Münster: Westfälisches Dampfboot, pp. 110-134.

Dejung, C. (2007), 'Dissonant memories. National Identity, Political Power, and the Commemoration of World War Two in Switzerland', in Oral History, 35(2), pp. $57-66$.

- (2006), Aktivdienst und Geschlechterordnung. Eine Kultur- und Alltagsgeschichte des Militärdienstes in der Schweiz 1939-1945, Zürich: Chronos.

— (2005), 'Soldatenmütter und Offiziersmatratzen. Die Frauenhilfsdienste und die Frage der politischen Gleichstellung der Frauen in der Schweiz 1938-1945', in Ariadne, Forum für Frauen- und Geschlechtergeschichte, 47, pp. 32-37.

_ , Gull, T. and Wirz, T. (eds) (2002), Landigeist und Judenstempel. Erinnerungen einer Generation 1930-1945, Zürich: Limmat.

— Interview with K. Meier, 15 December 2000.

Interview with R. Winkler (Archimob / Archives of the Mobilization oral history project), 1 December 2000.

- Interview with H. Fankhauser-Huber (Archimob), 5 September 2000.

- Interview with J. Christen, 19 May 2000.

_- Interview with H. Haefliger, 30 March 2000.

- Interview with H. P. Dreier (Archimob), 10 March 2000.

Interview with K. Keusch, 24 February 2000a.

- Interview with M. Pletscher, 24 February 2000b.

— Interview with M. Brügger (Archimob), 11 February 2000.

Interview with H. Wymann (Archimob), 7 July 1999.

Dienstreglement 1933 der schweizerischen Armee (1932), Bern: Schweizerische Armee.

Dinges, M. (2005), '"Hegemoniale Männlichkeit" - Ein Konzept auf dem Prüfstand', in M. Dinges (ed.), Männer - Macht - Körper, Hegemoniale Männlichkeit vom Mittelalter bis heute, Frankfurt a.M. and New York: Campus, pp. 7-33.

Erdheim, M. (1982), "Heisse" Gesellschaften und "kaltes" Militär', in Kursbuch. 67 , pp. $59-70$.

Frevert, U. (2001): Die Kasernierte Nation: Militärdienst und Zivilgesellschaft in Deutschland, München: Beck.

(1997a), 'Soldaten, Staatsbürger. Überlegungen zur historischen Konstruktion von Männlichkeit', in 'T. Kühne (ed.), Männergeschichte - Geschlechtergeschichte. 
Männlichkeit im Wandel der Moderne, Frankfurt a.M and New York: Campus, pp. 69-87.

(1997b), 'Gesellschaft und Militär im 19. und 20. Jahrhundert: Sozial-, kultur- und geschlechtergeschichtliche Annäherungen?' in U. Frevert (ed.), Militär und Gesellschaft im 19. und 20. Jahrhundert, Stuttgart: Klett-Cotta, pp. $7-14$.

Frey, O. (1937), 'Der Leutnant', in Festschrift für Ulrich Wille. Zum 60. Geburtstag, Zürich and Leipzig: Albert Müller, pp. 191-201.

Frisch, M. (1974), Dienstbüchlein, Frankfurt a.M.: Suhrkamp.

Gautschi, W. (1968), Der Landesstreik 1918, Zürich: Benziger.

Gruner, E. (ed.) (1973), 'Junge Schweizer erleben den Zweiten Weltkrieg', in Berner Zeitschrift für Geschichte und Heimatkunde, 35( 1), pp. 129-176.

Hagmann, D. and K. Trüeb (1989), 'Jetz brucht's e ganze Schwyzerma', in Reduit Basel 39/45. Katalog zur Ausstellung des Historischen Museums Basel in der Stückfärberei Kleinhüningen, Basel: Friedrich Reinhardt, pp. 114-123.

Hanselmann, H. (1944), Werktag in der Liebe und Ehe, Zürich: Rotapfel.

Hausamann, H. (1938a), 'Aushebung! Der grosse Tag des Rekruten Hans Bolliger von Uerkheim', in Schweizer Illustrierte Zeitung, 30, pp. 932-933.

(1938b), 'Du siehst das Heer und erkennst das Volk', in Schweizer Illustrierte Zeitung, 30, pp. 936-39.

Hobsbawm, E. (1995), Age of Extremes. The Short Twentieth Century, 1914-1991, London: Michael Joseph.

Hugger, P. (1999), “'Trostlos, aber verflucht romantisch". Tagebuchnotizen eines Soldaten 1939/40', Zürich: Limmat.

Hummler, F. (1944), 'Der Grenzsoldat', in Schweizerische Offiziersgesellschaft (ed.), Bürger und Soldat. Festschrift für Henri Guisan, Zürich: Orell Füssli, pp. 411-37.

Imhof, K. (1996), 'Das kurze Leben der geistigen Landesverteidigung. Von der "Volksgemeinschaft" vor dem Krieg zum Streit über die "Nachkriegsschweiz" im Krieg', in K. Imhof, H. Kleger and G. Romano (eds), Konkordanz und Kalter Krieg. Analyse von Medienereignissen in der Schweiz der Zwischen- und Nachkriegszeit, Zürich: Chronos, pp. 19-83.

Jaun, R. (1999), Preussen vor Augen. Das schweizerische Offizierskorps im militärischen und gesellschaftlichen Wandel des Fin de siècle, Zürich: Chronos.

- (1995), 'Zur Akzentuierung der Geschlechtscharaktere in der Belle Epoque in der Schweiz', in R. Jaun and B. Studer (eds), weiblich - männlich. Geschlechterverhältnisse in der Schweiz, Rechtsprechung, Diskurs, Praktiken, Zürich: Chronos, pp. 117-127.

Joris, E. (1990), 'Die Schweizer Hausfrau', in S. Brändli et al. (eds), Schweiz im Wandel. Studien zur neueren Gesellschaftsgeschichte, Festschrift für Rudolf Braun zum 60. Geburtstag, Basel and Frankfurt a. M.: Helbing \& Lichtenhahn, pp. 99-116.

Jost, H.U. (1992), Die reaktionäre Avantgarde. Die Geburt der neuen Rechten in der Schweiz um 1900, Zürich: Chronos.

Kappeler, E. (1942), 'Im Schülerhilfsdienst', in G. H. Heer and W. A. Classen (eds), Das Buch vom Schweizer Soldaten, Zürich: Sciencia, pp. 308-326.

Kreis, G. (1976), Auf den Spuren von La Charité. Die schweizerische Armeeführung im Spannungsfeld des deutsch-französischen Gegensatzes 1936-1941. Basel and Stuttgart: Helbing \& Lichtenhahn.

Kühne, T. (1997), ““ . . . aus diesem Krieg werden nicht nur harte Männer heimkehren." Kriegskameradschaft und Männlichkeit im 20. Jahrhundert', in 
T. Kühne (ed.), Männergeschichte, Geschlechtergeschichte. Männlichkeit im Wandel der Moderne, Frankfurt a.M. and New York: Campus, pp. 174-192.

(1999), 'Der Soldat', in Ute Frevert and Heinz-Gerhard Haupt (eds), Der Mensch des 20. Jahrhunderts, Frankfurt a. M. and New York: Campus, pp. 344-372.

Kurz, H.R. (1985), Die Geschichte der Schweizer Armee, Frauenfeld: Huber.

Lengwiler, M. (1995), 'Soldatische Automatismen und ständisches Offiziersbewusstsein. Militär und Männlichkeit in der Schweiz um 1900', in R. Jaun and B. Studer (eds), weiblich - männlich. Geschlechterverhältnisse in der Schweiz, Rechtsprechung, Diskurs, Praktiken, Zürich: Chronos, pp. 171-184.

Meier, N. (2004), 'Gustav Dänikers Haltung zum Nationalsozialismus und seine Deutung des Krieges', in Militärgeschichtliche Studien I, MILAK Schrift Nr. 2, pp. 79-117.

Mesmer, B. (2007), Staatsbürgerinnen ohne Stimmrecht. Die Politik der schweizerischen Frauenverbände 1914-1971, Zürich: Chronos.

Mooser, J. (1997), 'Die "Geistige Landesverteidigung" in den 1930er Jahren. Profile und Kontexte eines vielschichtigen Phänomens der schweizerischen politischen Kultur in der Zwischenkriegszeit', in Schweizerische Zeitschrift für Geschichte, 47, pp. 685-708.

Mosse, G.L. (1996), The Image of Man. The Creation of Modern Masculinity, New York: Oxford University Press.

Neval, D. (2004), 'Der deutsche Russlandfeldzug aus der Sicht von Oberst Gustav Däniker', in Militärgeschichtliche Studien I, I, MILAK Schrift Nr. 2, pp. 123-132.

Nye, R.A. (2007), 'Review Essay: Western Masculinities in War and Peace', in American Historical Review, 112, pp. 417-438.

Regard, F. and L. Neury (2002), La vie . . malgré tout. Mémoire d'une Suisse en guerre, Yens sur Morges: Cabédita.

Roper, M. (2005), 'Slipping Out of View: Subjectivity and Emotion in Gender History', in History Workshop Journal 59, pp. 57-72.

Rückblickend (2004), Eine Sammlung von 21 Filmen in Zusammenarbeit mit der Wanderausstellung "L'Histoire c'est moi", Zürich: Limmat (television documentary).

Schaer, E. (1940), 'Wehrpsychologische Fragen. Gedanken und Anregungen aus dem Aktivdienst', in Allgemeine Schweizerische Militärzeitung, February, pp. 52-66.

Schibler, E. (1907), Die Armee, die Beschützerin unserer Freiheit, Frauenfeld: Huber.

Schmid-Ammann, P. (1939), in Die Nation, 8. Juni, cit. after P. Schmid-Ammann (1971). Mahnrufe in die Zeit. Vier bewegte Jahrzehnte schweizerischer Politik, Zürich: Conzett \& Huber, p. 87.

Schuhmacher, E. (1939), 'Über Wesen und Pflicht des Schweizer Offiziers', in Schriften der Avia, 1.

Scott, J. (1986), 'Gender: A Useful Category of Historical Analysis', in American Historical Review, 91, pp. 1053-1075.

Spinnler, P. (1940), 'Unsere Milizarmee', in Die Ernte. Schweizerisches Jahrbuch, p. 112.

Stampfli, O. (1944), 'Unsere Armee als volkserzieherische Institution', in Schweizerische Offiziersgesellschaft (ed.), Bürger und Soldat. Festschrift für Henri Guisan, Zürich: Orell Füssli, pp. 313-327.

Stämpfli, R. (2002), Mit der Schürze in die Landesverteidigung, Frauenemanzipation und Schweizer Militär 1914-1945, Zürich: Orell Füssli.

Tanner, J. (1997), 'Militär und Gesellschaft in der Schweiz nach 1945', in Ute Frevert (ed.), Militär und Gesellschaft im 19. und 20. Jahrhundert, Stuttgart: KlettCotta, pp. 314-340. 
Tosh. J. (2004), 'Hegemonic masculinity and the history of gender', in S. Dudink; K. Hagemann and J. Tosh (eds), Masculinities in politics and war. Gendering modern history, Manchester: Manchester University Press, pp. 41-58.

Uhlmann, E. (1944), 'Der Milizoffizier', in Schweizerische Offiziersgesellschaft (ed.), Bürger und Soldat. Festschrift für Henri Guisan, Zürich: Orell Füssli, pp. 397-409.

Vetter, R.C. (1940), Soldatische Grundlagen für den schweizerischen Infanteristen, Frauenfeld: Huber.

'Wie wir unsere Rekrutenschule erlebten. Erinnerungen an die Inf. R.S. II/7 1942. III. Kp.', without city or date [1942/3].

Wille, U. (1930), 'Gründlichkeit und Initiative', in Allgemeine Schweizerische Militärzeitung, pp. 161-68.

Zeller, R. (1999), Emil Sonderegger. Vom Generalstabschef zum Frontenführer, Zürich: NZZ Verlag.

Zimmer, O. (1996), 'Die "Volksgemeinschaft". Entstehung und Funktion einer nationalen Einheitssemantik in den 1930er Jahren in der Schweiz', in K. Imhof; H. Kleger and G. Romano (eds), Konkordanz und Kalter Krieg. Analyse von Medienereignissen in der Schweiz der Zwischen- und Nachkriegszeit, Zürich: Chronos, pp. 85-109.

\section{Acknowledgement}

I would like to thank Joanna Bourke, Martin Lengwiler, Karin S. Moser and the Journal of War and Culture Studies for their helpful comments on earlier versions of this article.

\section{Contributor details}

Dr Christof Dejung is Senior Lecturer and Researcher at the Department of History and Sociology at the University of Konstanz, Germany. His field of research includes works on the history of commemoration and on the cultural and gender history of the military service in Switzerland during the Second World War. Currently, he is writing a book on the social and cultural historical foundations of global trade in the nineteenth and twentieth centuries taking the example of the Swiss merchant house Volkart Brothers. Contact: University of Konstanz, Department of History and Sociology, Box D6, 78457 Konstanz, Germany. Telephone: 004144 3637942

E-mail: christof.dejung@uni-konstanz.de 